\title{
Duodenal ulcer, Helicobacter pylori, and gastric secretion
}

\author{
K Chandrakumaran, D Vaira, M Hobsley
}

Department of Surgery, University College London Medical School and Department of Gastroenterology, The Middlesex Hospital, London

K Chandrakumaran D Vaira $M$ Hobsley

Correspondence to: Professor M Hobsley, Department of Surgery, University College London Medical School, 67-73 Riding House Street, London W1P 7LD.

Accepted for publication 23 November 1993

\begin{abstract}
Patients with chronic dyspepsia were categorised by macroscopic appearance at oesophagogastroduodenoscopy as having duodenal ulceration (DU), other diagnosed lesions such as reflux oesophagitis, carcinoma of stomach, etc, or no organic lesion (non-ulcer dyspepsia, NUD). Material was collected to identify gastric infection with Helicobacter pylori (H pylori) by CP urease test, culture, and histological examination and to make the microscopic diagnosis of active chronic gastritis. Each patient in the DU and NUD categories was then invited to volunteer for a gastric secretion study in which maximal gastric secretion in response to histamine was measured. Sixty two gastric secretion tests were performed (31 DU, 31 NUD). The presence of $H$ pylori was associated with active chronic gastritis $(100 \%)$. DU patients secreted more acid than the NUD patients. $H$ pylori positivity was associated with decreased maximal gastric secretion in both groups. There was a positive correlation between smoking and maximal acid output shown only in $H$ pylori negative but not in $H$ pylori positive patients. These findings were clear cut when all corrections of maximal gastric secretion were made for pyloric loss, duodenogastric reflux, and stature. This study failed to show any aetiological link between $H$ pylori and DU by increased maximal gastric secretion. (Gut 1994; 35: 1033-1036)
\end{abstract}

Duodenal ulcer (DU) is a multifactorial disease, but since 1983 several studies have shown an association between duodenal ulcer and $H$ pylori. ${ }^{1-3}$ Two unproved hypotheses have been put forward to link $H$ pylori with the pathogenesis of duodenal ulcer. One suggests that high gastric acidity or rapid gastric emptying, or both by creating a low duodenal $\mathrm{pH}$, results in gastric metaplasia in the duodenum. ${ }^{4}$ This permits $H$ pylori from an area of antral active chronic gastritis to colonise the duodenum leading to duodenitis and thence to DU. ${ }^{5-9}$ The other hypothesis is that urease produced by $H$ pylori splits urea in the gastric juice into ammonia, which neutralises the acid in contact with the mucosa overlying the $G$ cells. This impairs the normal inhibition of gastrin release by intraluminal acid leading to an inappropriate secretion of gastrin in response to food and thereby an increase in acid output that leads to the ulcer. ${ }^{10-16}$
Maximal acid secretion in a subject has been shown to be related to the risk that the subject had a DU. ${ }^{17}$ Other agents postulated to be risk factors for DU can be assessed against the background of acid related risk. ${ }^{18}$ Thus patients with high acid secretion might not need to have any other risk factor present to express the ulcer, whereas patients with low gastric secretion will probably not develop an ulcer unless they are exposed to the putative factor. It follows that the link between maximal gastric secretion and the risk factor might not be the simple one of duodenal ulcer, $H$ pylori, and high maximal secretion.

The purpose of this study was to find out if $H$ pylori was one of the risk factors necessary to cause DU in patients with low gastric acid output, or if it was associated with an increased parietal cell mass.

\section{Subjects and methods}

From January 1988 to July 1990 two of the authors (KC and DV) undertook 206 diagnostic endoscopies in the department of gastroenterology, The Middlesex Hospital. Forty six further patients had an endoscopy at two neighbouring centres.

Patients were divided into three groups based on the endoscopic findings: (1) DU (76 subjects), (2) any other macroscopic lesion (53 subjects), and (3) no macroscopic lesion of oesophagus, stomach or duodenum (non-ulcer dyspepsia (NUD), 123 subjects). Duodenitis was not specified nor was a biopsy specimen taken from the duodenum to attempt a histological diagnosis of duodenitis.

Each patient in the DU and NUD categories was told the macroscopic diagnosis and invited to volunteer for a gastric secretion study. Patients who had taken steroids, non-steroidal anti-inflammatory drugs, antibiotics or colloidal bismuth subcitrate within the previous three months or who had had gastric surgery were excluded. Of the volunteers who finally attended for gastric secretion studies, there were 31 of 76 in the DU group, 31 of 123 in the NUD group. The study had the approval of the clinical investigations panel of The Middlesex Hospital.

Three antral biopsy specimens were taken during the endoscopy procedure. The CP urease test (CP Test, Gist-Brocades Farma, Spa, Italy) was performed in the endoscopic suite using the method described by Vaira et $a l .{ }^{19}$ The presence or absence of active chronic gastritis was determined in histological sections of biopsy specimens stained with haematoxylin and eosin, using the classification 
TABLE I Relation between maximal gastric secretion, expressed in four different ways for (a) DU v NUD and (b) $\mathrm{H}$ pylori negativity and positivity

\begin{tabular}{|c|c|c|c|c|}
\hline Group & $\begin{array}{l}\text { MAO } \\
\left(\mathrm{mmol} \mathrm{h}^{-1}\right)\end{array}$ & $\begin{array}{l}M A O \text { (ht std) } \\
\left(m m o l h^{-1}\right)\end{array}$ & $\begin{array}{l}V g \\
\left(m l h^{-1}\right)\end{array}$ & $\begin{array}{l}V g(h t s t d) \\
\left(m l h^{-1}\right)\end{array}$ \\
\hline $\begin{array}{l}\text { DU }(\mathrm{n}=31) \\
\text { NUD }(\mathrm{n}=31) \\
\% \text { Difference } \\
\text { Wilcoxon } \\
\text { H pylori negative }(\mathrm{n}=21) \\
\text { H pylori positive }(\mathrm{n}=41) \\
\% \text { Difference } \\
\text { Wilcoxon }\end{array}$ & $\begin{array}{l}47 \cdot 90 \\
25 \cdot 75 \\
46 \cdot 24 \\
S \\
39 \cdot 68 \\
34 \cdot 34 \\
13 \cdot 45 \\
\text { NS }\end{array}$ & $\begin{array}{l}49 \cdot 60 \\
27 \cdot 31 \\
44 \cdot 93 \\
S \\
42 \cdot 13 \\
36 \cdot 58 \\
13 \cdot 17 \\
\text { NS }\end{array}$ & $\begin{array}{l}383 \\
188 \\
50 \cdot 9 \\
S \\
323 \\
267 \\
17 \cdot 3 \\
\text { NS }\end{array}$ & $\begin{array}{l}395 \\
203 \\
48 \cdot 6 \\
S \\
339 \\
274 \\
S^{19 \cdot 1}\end{array}$ \\
\hline
\end{tabular}

$\mathrm{MAO}=$ maximal acid output, $\mathrm{Vg}=$ corrected volume of gastric secretion, ht std =height standardised $($ for $170 \mathrm{~cm})$. NS = not significant $(p>0.05) ; S=$ significant $(p<0.05)$

TABLE II Relation between maximal gastric secretion and $\mathrm{H}$ pylori state in the DU group: influence of corrections for the measurement of gastric secretion

\begin{tabular}{|c|c|c|c|c|}
\hline & $\begin{array}{l}\text { MAO } \\
\left(\text { mmol } h^{-1}\right) \\
\text { mean }(S D)\end{array}$ & $\begin{array}{l}\text { MAOs } \\
\left(\text { mmol } h^{-1}\right) \\
\text { mean }(S D)\end{array}$ & $\begin{array}{l}V g \\
\left(m l h^{-1}\right) \\
\text { mean }(S D)\end{array}$ & $\begin{array}{l}V g s \\
\left(\mathrm{ml} \mathrm{h}^{-1}\right) \\
\text { mean }(S D)\end{array}$ \\
\hline $\begin{array}{l}\text { H pylori positive }(\mathrm{n}=21) \\
\text { H pylori negative }(\mathrm{n}=10) \\
\% \text { Reduction } \\
\text { Wilcoxon }\end{array}$ & $\begin{array}{l}45 \cdot 28(15 \cdot 12) \\
53 \cdot 41(13 \cdot 75) \\
15 \cdot 0 \\
\text { NS }\end{array}$ & $\begin{array}{l}47 \cdot 82(14 \cdot 08) \\
53 \cdot 35(14 \cdot 94) \\
10 \cdot 3 \\
\text { NS }\end{array}$ & $\begin{array}{l}361(68) \\
429(79) \\
15 \cdot 8 \\
S\end{array}$ & $\begin{array}{l}374(73) \\
439(100) \\
14 \cdot 8 \\
S\end{array}$ \\
\hline
\end{tabular}

Abbreviations as in Table I

criteria of Whitehead ${ }^{20}$ as modified by Warren and Marshall. ${ }^{21} \mathrm{H}$ pylori was identified microscopically in sections with Giemsa staining and in culture on blood agar medium with $6 \mathrm{mg} / \mathrm{ml}$ of amphotericin. ${ }^{22}$ Gastric secretion studies were performed by a standard technique. ${ }^{1823}$ The salient features were that the studies started at 0830 , the patient had fasted for at least eight hours, and smoking and alcohol had been proscribed for 12 hours. Also, for 72 hours before the test the subjects were asked to stop taking $\mathrm{H}_{2}$ antagonists and any other treatment known to change the gastric secretion or motility, or both. After a basal one hour period, an intravenous infusion of histamine acid phosphate, $40 \mu \mathrm{g} \mathrm{kg}^{-1} \mathrm{~h}^{-1}$ was started and 10 minute samples were analysed for volume and titratable acidity; corrections were made for pyloric losses and duodenogastric reflux, and allowance made for stature (height). Gastric

TABLE III Relation between maximal gastric secretion and $\mathrm{H}$ pylori state in the NUD group: influence of corrections for the measurement of gastric secretion

\begin{tabular}{|c|c|c|c|c|}
\hline & $\begin{array}{l}M A O \\
\left(\text { mmol } h^{-1}\right) \\
\text { mean }(S D)\end{array}$ & $\begin{array}{l}\text { MAOs } \\
\left(\text { mmol } h^{-1}\right) \\
\text { mean }(S D)\end{array}$ & $\begin{array}{l}V g \\
\left(m l h^{-1}\right) \\
m e a n(S D)\end{array}$ & $\begin{array}{l}V g s \\
\left(\text { ml h }^{-1}\right) \\
\text { mean }(S D)\end{array}$ \\
\hline $\begin{array}{l}\text { H pylori positive }(\mathrm{n}=20) \\
H \text { pylori negative }(\mathrm{n}=11) \\
\% \text { Reduction } \\
\text { Wilcoxon }\end{array}$ & $\begin{array}{l}22 \cdot 86(10 \cdot 90) \\
31 \cdot 01(12 \cdot 86) \\
26 \cdot 2 \\
S\end{array}$ & $\begin{array}{l}24 \cdot 77(11 \cdot 67) \\
31 \cdot 92(10 \cdot 11) \\
22 \cdot 3 \\
S\end{array}$ & $\begin{array}{l}168(75) \\
225(51) \\
25 \cdot 3 \\
S\end{array}$ & $\begin{array}{l}188(74) \\
230(46) \\
18 \cdot 2 \\
S\end{array}$ \\
\hline
\end{tabular}

Abbreviations as in Table I.

TABLE IV Correlation between smoking factor (square root of cigarettes per day multiplied by years of smoking) with maximal gastric secretion in DU and NUD patients (Kendall's rank correlation coefficient $\tau$

\begin{tabular}{|c|c|c|c|c|}
\hline & \multicolumn{4}{|c|}{ Helicobacter pylori negative patients only } \\
\hline & $\begin{array}{l}\text { MAO } \\
\left(\text { mmol } h^{-1}\right) \\
\text { mean }(S D)\end{array}$ & $\begin{array}{l}\text { MAOs } \\
\left(\text { mmol } h^{-1}\right) \\
\text { mean }(S D)\end{array}$ & $\begin{array}{l}V g \\
\left(m l h^{-1}\right) \\
\text { mean }(S D)\end{array}$ & $\begin{array}{l}V g s \\
\left(\text { ml h}^{-1}\right) \\
\text { mean }(S D)\end{array}$ \\
\hline $\mathrm{DU}(\mathrm{n}=10)$ & $\begin{array}{l}53 \cdot 41(13.75) \\
\tau=0 \cdot 198 \\
\text { NS }\end{array}$ & $\begin{array}{l}53 \cdot 35(14 \cdot 94) \\
\tau=0 \cdot 188 \\
\text { NS }\end{array}$ & $\begin{array}{l}429(79) \\
\tau=0 \cdot 288 \\
S\end{array}$ & $\begin{array}{l}439(100) \\
\tau=0.301 \\
S\end{array}$ \\
\hline Non-DU $(n=11)$ & $\begin{array}{l}31 \cdot 01(12 \cdot 86) \\
\tau=0.303 \\
\text { NS }\end{array}$ & $\begin{array}{l}31.92(10 \cdot 11) \\
\tau=0 \cdot 361 \\
\text { NS }\end{array}$ & $\begin{array}{l}225(51) \\
\tau=0.410 \\
S\end{array}$ & $\begin{array}{l}230(46) \\
\tau=0 \cdot 441 \\
S\end{array}$ \\
\hline
\end{tabular}

Abbreviations as in Table I. secretion was thus expressed in four different ways - as the raw data of plateau average maximal acid output obtained as the product of titratable acidity and volume, as $\mathrm{Vg}$ - the pyloric loss corrected, reflux corrected volume of pure gastric juice, ${ }^{23}$ and as each of these standardised to a height of $170 \mathrm{~cm} .{ }^{24}$

\section{STATISTICAL ANALYSIS}

Data were expressed in means and standard deviations. Gastric secretion groups were compared by a non-parametric test, the Wilcoxon signed rank test, because gastric secretion was not normally distributed in the population. Contingency table analysis with $\chi^{2}$ or Fisher's exact test was used depending on the numbers within the smallest cells. Kendall's $\tau$ was used to assess the correlation between smoking and gastric secretion. A value of $\mathrm{p}<0.05$ was considered to be statistically significant.

\section{Results}

Two hundred and fifty two patients (100 men, 152 women; average age 50.8 years, range 16-79) had an endoscopy. Fifty three patients had miscellaneous macroscopic findings other than duodenal ulcer. These 53 patients were not approached for gastric secretion studies. A duodenal ulcer was diagnosed in $76(30 \%)$ and no abnormality, that is no ulcer disease (NUD) was found in $123(49 \%)$. The CP urease test was positive in $145(58 \%)$ and negative in 107 $(42 \%)$. All CP urease positive patients were also positive by culture or sensitivity or both.

The final decision for $H$ pylori infection in the stomach was made according to whether culture or sensitivity (or both) was (were) positive: by these criteria, 159 patients $(63 \%)$ were $H$ pylori positive. In the DU group, 9 of 17 patients below the age of 36 and 44 of the 59 patients aged 36 or more were $H$ pylori positive.

Active chronic antral gastritis was present in sections of mucosa in all $H$ pylori positive subjects but was absent in all $H$ pylori negative patients.

Maximal gastric secretion was higher in patients with DU than in those without DU whichever method was used to show secretion (Table I). Within each of these main groups maximal gastric secretion was $15-18 \%$ lower in those with $H$ pylori compared with those without (Tables II and III). This second statement was correct when secretion was expressed as height standardised Vg. Tables II and III show the effect of using the less accurate indices (Vg unstandardised, acid output unstandardised, and standardised).

Of the two subjects who attended for gastric secretion studies, 33 (18 men, 15 women) were smokers, 29 ( 21 men, 8 women) were non-smokers. In smokers, positive correlations between smoking factor, that is the square root of the product of the number of cigarettes smoked per day and the number of years smoked, and maximal gastric secretion were shown in $H$ pylori negative (both ulcer and non-ulcer) groups, but once again only if the 
secretion was expressed as Vg (Table IV). In patients who were $H$ pylori positive, however, there was no correlation between gastric secretion and smoking, however secretion rate was expressed or whether the patient had a DU.

In the range of standardised $\mathrm{Vg}$ of $270-321$ $\mathrm{ml}$ there was an overlap between the DU and NUD groups consisting of six DU and six NUD subjects. All six of the DU group, but also four of the NUD, were $H$ pylori positive. Subdividing the DU group into those lying within the normal range previously reported from this department, ${ }^{23}$ that is below $425 \mathrm{ml}$, and those above this range and therefore statistically hypersecretors, there were 23 in the normal range and eight hypersecretors. The $H$ pylori positive subjects were distributed as 17 of 23 in the normal range (74\%) and four of eight in the hypersecretors $(50 \%)$. This difference is not significant (Fisher's exact test, $\mathrm{p}=0.1731)$. If it is accepted that $H$ pylori reduces gastric secretion by $17 \%$ and we increase the secretion values of the $H$ pylori positive DU patients by about $17 \%$, they now split as 11 hypersecretors and 10 hyposecretors. This emphasises the fact that $H$ pylori is not apparently summating with low gastric secretion to produce a DU.

\section{Discussion}

We studied $H$ pylori in relation to DU, NUD, and a group of miscellaneous diagnoses. We decided not to include duodenitis in our diagnostic categories because this condition is difficult to diagnose/quantify. ${ }^{25} 26$

The presence of $H$ pylori was $100 \%$ associated with active chronic gastritis and vice versa. Culture and histological examination for $H$ pylori gave almost identical results, and the specificity of the urease test in relation to the others suggests that all three methods used were reliable and at least comparable with the results of other workers. ${ }^{27-30}$ The accuracy of gastric secretion results in our laboratory is high and the evidence has been published elsewhere. ${ }^{18}$

The most notable positive finding of our study was that $H$ pylori infection was associated, both in the DU and NUD groups, with decreased maximal gastric secretion. The effect was only clear cut when all corrections had been made for pyloric loss, duodenogastric reflux, and stature and emphasises the importance of taking these factors into account, especially when small numbers of subjects have been studied. Failure to make such corrections probably accounts for the discrepancies in published works; Brady et al,,$^{31}$ Hui et al, ${ }^{32}$ and Kang et $a l^{33}$ found no consistent relation between $H$ pylori and acid secretion, Wanger et $a l^{34}$ found no difference in intragastric acidity in $H$ pylori positive and negative patients but acidity was higher in DU subjects, Levi et al ${ }^{11-13}$ and McColl et al ${ }^{14}$ claimed $H$ pylori increased gastric secretion and in contrast Steer studied 17 DU patients and showed a negative correlation between the number of $H$ pylori and acid output. ${ }^{35}$ Our data are consistent with the findings of Steer but not with those of others.
The patients in the DU and NUD groups who had overlapping gastric secretion showed no evidence of any predilection of the organism for the DU group. Again, this argues against an aetiological role for $H$ pylori but we accept that the numbers were small. There was a disproportionately large incidence of $\mathrm{H}$ pylori in the DU normosecretors compared with the hypersecretors. At first glance this finding fits the suggestions made previously ${ }^{17}$ that aetiological factors other than acid might have an additive effect so that smaller acid outputs might in their presence be sufficient to produce an ulcer compared with the amount of acid needed in their absence. In the light of all our evidence, however, we believe that the likelier explanation of this phenomenon is that $H$ pylori reduces gastric secretion. If we increase the maximal acid output by $17 \%$ (that is the figure by which $H$ pylori on average reduces gastric secretion) of all DU and NUD $H$ pylori positive patients then the asymmetry of $H$ pylori positivity between normosecretors and hypersecretors vanishes.

The comparative antral hypoacidity produced by $H$ pylori could fit the observed tendency to hypergastrinaemia, and in this respect the effect of $H$ pylori is similar to that of acute cigarette smoking. ${ }^{36}$ Chronic cigarette smoking, however, gives rise to an increased parietal cell mass and hyperacidity. ${ }^{36-39}$ This does not occur with $H$ pylori. The reason is possibly that $H$ pylori produces its hypoacidity not pharmacologically (as smoking does) but pathologically, that is by destroying parietal cells ${ }^{40-42}$ and so there is no chance for the increase in parietal cells to develop. This suggestion is supported by our finding that the increase in maximal gastric secretion with overall dose of cigarettes (smoking factor) was demonstrable in $H$ pylori negative subjects, but not in $H$ pylori positive subjects. The regressions between smoking and maximal secretion were only statistically significant with $\mathrm{Vg}$ standardised for height, yet another reason that all gastric secretion studies should be corrected for pyloric loss and duodenogastric reflux and standardised for stature, if useful information is not to be lost.

We failed to show any evidence of an aetiological link acting by raised maximal gastric secretion between DU and $H$ pylori: indeed, the predominant aetiological factor for DU in our series was increased maximal gastric secretion and the association of $H$ pylori with reduced gastric secretion makes it unlikely that the organism is an aetiological factor.

The hypothesis that $H$ pylor i is an important factor in the aetiology of duodenal ulcer rests upon three lines of evidence: (1) an increased incidence of $H$ pylori in patients with duodenal ulcer compared with controls; (2) the claim that $H$ pylori increases gastric secretion; and (3) the well documented reports from several centres that eradicating the organism results in healing with longer relapse free interval than $\mathrm{H}_{2}$ antagonists and proton pump inhibitors can achieve. We present in this paper evidence that seems to deny the acid link, at least as far as the parietal cell mass is concerned. 
1 Marshall BJ, McGechie DB, Rogers PA, Glancy RJ. Pyloric Campylobacter infection and gastroduodenal disease. Med $\mathcal{f}$ A ust 1985; 142: 439-44.

2 Coghlan JG, Gilligan D, Humphries H, McKenna D, Dooley C, Sweeney E, et al. Campylobacter pylori and recurrence of duodenal ulcers - a 12 months follow-up study. Lancet 1987; ii: 1109-11.

3 Rauws EAJ, Langenberg W, Houthoff $\mathrm{HJ}$, Zanen $\mathrm{HC}$ Tytgat GNJ. Campylobacter pyloridis - associated chronic active antral gastritis; a prospective study of its prevalence and the effects of antibacterial and antiulcer treatment. Gastroenterology 1988; 94: 33-40.

4 James AH. Gastric epithelium in the duodenum. Gut 1964; 5: $285-94$.

5 Wyatt JI, Rathbone BJ, Dixon MF, Heatley RV. Campylobacter pyloridis and acid induced gastric metaplasia in the pathogenesis of duodenitis. F Clin Pathol plasia in the patho

6 Wyatt JI, Rathbone BJ, Dixon MF, Heatley RV, Axon ATR Campylobacter pylori and development of duodenal ulcer [letter]. Lancet 1988; i: 118 .

7 Goodwin CS. Duodenal ulcer, Campylobacter pylori and the 'leaking roof' concept. Lancet 1988; ii: 1467-9.

8 Wyatt JI. The role of Campylobacter pylori in the pathogenesis of peptic ulcer disease. Scand $\mathscr{f}$ Gastroenterol 1989; 24 (suppl 157): 7-11.

9 Goodwin CS, Gordon A, Burke V. Helicobacter pylori (Campylobacter pylori) and duodenal ulcer [editorial]. Med $\mathcal{F}$ Aust 1990; 153: 66-7.

10 Levi S, Beardshall A, Haddad G, Ghosh P, Geardshall K, Playford $\mathrm{R}$, et al. Campylobacter pylori and duodenal ulcer: gastrin link. Lancet 1989; i: 1167-8.

11 Levi S. Campylobacter pylori and duodenal ulcer disease and gastrin. BMF 1989; 299: 1093-4.

12 Levi S, Beardshall K, Desa LA, Calam J. Campylobacter pylori gastrin, acid secretion and duodenal ulcer [letter] Lancet 1989; ii: 613

13 Levi S, Davies KAA, Playford R, Ghosh P, Price MJ, Calam $\mathrm{J}$, et al. Antral Helicobacter pylori, hypergastrinaemia and duodenal ulcer: effects of eradicating the organisms. $B M \mathcal{F}$ 1989; 299: 1504-5.

14 McColl KEL, Fullarton GM, Nujumi AM, McDonald AM, Brown IL, Hilditch TE. Lowered gastrin and gastric acidity after eradication of Campylobacter pylori in duodenal ulcer. Lancet 1989; ii: 499-500.

15 Graham DY, Opekun AR, Lew GM, Klein PD, Walsh JH. Helicobacter pylori infection and gastrin release in duodenal ulcer patients. Gastroenterology 1990; 98: A52.

16 McColl KEL, Fullarton GM, Chittajalu R, El Nujumi AM, McDonald AMI, Dahill SW, et al. Plasma gastrin, daytime intragastric $\mathrm{pH}$ and nocturnal acid output before and time intragastric $\mathrm{pH}$ and nocturnal acid output before and
1 and 7 months after eradication of Helicobacter pylori duodenal ulcer subjects. Scand $\mathcal{F}$ Gastroenterol 1991; 26: duodenal

17 Hobsley M, Whitfield PF. The likelihood of a disease in relation to the magnitude of a risk factor: the example of duodenal ulcer. Theor Surg 1987; 2: 106-9.

18 Whitfield PF, Hobsley M. A standardised technique for the performance of accurate gastric secretion studies. Agents Actions 1979; 9: 327-32.

19 Vaira D, Holton J, Cairns S, Falzon M, Polydorou A Dowsett J, et al. Urease tests for Campylobacter pylori (CP): care in interpretation. F Clin Pathol 1988; 41: 812-3.

20 Whitehead R, Truelove SC, Gear MWL. The histological diagnosis of chronic gastritis in fiberoptic gastroscope diagnosis of chronic gastritis in fiberoptic gastr

21 Warren JR, Marshall B. Unidentified curved bacilli on gastric epithelium in active chronic gastritis. Lancet 1983; i: 1273 .
22 Vaira D, Holton J, Falzon M, Cairns S, Dowestt J, Polydorou A, et al. Investigation of Campylobacter pylor associated gastritis by histology, culture, urease tests, brushings and antibody levels. Ital f Gastroenterol 1988;
20: 299-304.

23 Hassan MA, Hobsley $M$. The accurate assessment of maximal gastric secretion in control subjects and patients with duodenal ulcer. Br F Surg 1971; 58: 171-9.

24 Hobsley M, Whitfield PF, Faber PG, Parkin JV Hypersecretion and length of history in duodenal ulceration. Lancet 1975; ii: 101-4.

25 Johnsen R, Brenersen B, Straume B, Førde OH, Bostad L Burtol PG. Prevalence of endoscopic and histological findings in subjects with and without dyspepsia. $B M \mathcal{F}$ 1991; 302: 749-52.

26 Inatsuchi I, Tanaka M, Tresaki $T$, et al. Clinical diagnosis of duodenitis [abstract]. 1992: The World Congress of Gastroenterology, Sydney, Australia, 649.

27 Marshall BJ, Warren JR, Francis JG, Langton SR, Goodwin $\mathrm{CS}$, Blincow ED. Rapid urease test in the management of Campylobacter pyloridis-associated gastritis. $\mathrm{Am} \mathscr{f}$ ; 82: $200-10$

28 Hazell SL, Broody TJ, Gal, Lee A. Campylobacter pyloridis I. Detection of urease as a marker of bacterial colonisation and gastritis. Am $\mathcal{f}$ Gastroenterol 1987; 82: 292-8.

29 McNulty CAM, Dent JC, Uff JC, Gear MWL, Wilkinson SP. Detection of Campylobacter pylori by the biopsyurease test: assessment in 1445 patients. Gut 1989; 30: 1058-62.

30 Dooley PC, Cohen H, Fitzgibbons PL, Bauer M, Appleman MD, Perez-Perez GI, et al. Prevalence of Helicobacter pylori infection and histologic gastritis in asymptomatic persons. N Engl f Med 1989; 321: 1562-6.

31 Brady CE, Hadfield TL, Hyatt JR, Utts SJ. Acid secretions and serum gastrin levels in individuals with and serum gastrin levels in individuals with

Hui WM, Lam SK, Chau PY, Ho J, Lui I, Lai CL, et al. Persistence of Campylobacter pyloridis despite healing of duodenal ulcer and improvement of accompanying duodenitis and gastritis. Dig Dis Sci 1987; 32: 1255-60

33 Kang JY, Wee A. Helicobacter pylori and gastric acid output in peptic ulcer disease. Dig Dis Sci 1991; 31: 5-9.

34 Wagner S, Schuller A, Gebel M, Freise J, Schmidt FW. Campylobacter pylori and acid secretion. Lancet 1989; ii: 262-8.

35 Steer H. Mucosa-related bacteria in the stomach [letter] Lancet 1984; ii: 528 .

36 Roxburgh JC. The acute and chronic effects of cigarette smoking on gastric secretion. Gut 1992; 33: 1170-3.

37 Parente F, Lazzaroni M, Sangaletti O, Baroni S, Porro GB. Cigarette smoking, gastric secretion and serum pepsinogen I concentration in duodenal ulcer patients. Gut 1985; 26: 1327-32.

38 Massarrat S, Enschai F, Pittner PM. Increasing gastric secretory capacity in smokers without gastrointestinal lesions. Gut 1986; 27: 433-9.

39 Whitfield PF, Hobsley M. Comparison of maximal gastric secretion in smokers and non-smokers with and without duodenal ulcer. Gut 1987; 28: 557-60.

40 Wiersinger WM, Tytgat GNJ. Clinical recovery owing to target parietal cell failure in a patient with Zollingertarget parietal cell failure in a patient with Zollinger-

41 Defize J, Goldie J, Hunt RH. Effect of Campylobacter pylori on acid production by isolated guinea pig parietal cells. Gut 1988; 29: A1435.

42 Braga LL, Marshall BJ, Moreno H, Menzies D, McCallum RW, Guerrant RL. Helicobacter pylori and hypochlorhydria in asymptomatic Brazilian men. Gastroenterology 1990; 98: A274. 